\title{
追熟に伴うトマトおよびキウイフルーツ果実のクロロフィル蛍光スペクトル変化
}

\author{
福地健一* $\cdot$ 嘉数 (大野) 祐子 \\ 木更津工業高等専門学校２92-0041 千葉県木更津市清見台東 2-11-1
}

\section{Characteristics of Chlorophyll Fluorescence Spectra Variations in Tomato and Kiwi Fruits During Ripening}

\author{
Ken'ichi FUKUCHI* and Yuko KAKAZU-OHNO \\ National Institute of Technology, Kisarazu College, 2-11-1 Kiyomidai-Higashi, Kisarazu, Chiba, 292-0041, Japan
}

\begin{abstract}
In this study, we developed a non-destructive technique to evaluate fruit maturity based on fluorescence measurement and investigated its utility. The purpose of this technique is to adequately control the quality of climacteric fruits that show changes in taste and texture during ripening. The fluorescence maturity index (FMI), which is defined as the logarithm of F685/F740, was used for the evaluation. Here, F685 and F740 were the chlorophyll-a fluorescence intensity at 685 and $740 \mathrm{~nm}$, respectively. The fluorescence at wavelength $685 \mathrm{~nm}$ is strongly reabsorbed into chlorophyll-a. Therefore, F685 increases relative to F740 when the chlorophyll content of a fruit decreases during ripening. As a result, FMI increases. We excited fruits using a light wavelength of $620 \mathrm{~nm}$, which is not easily absorbed by carotenoids such as lycopene, and measured the fluorescence spectra emitted from the inside of the fruit. We ripened mature-green tomatoes 'HomeMomotaro' and examined the relationship between FMI and chromaticity ( $a^{*}$ value and $\mathrm{a}^{*} / \mathrm{b}^{*}$ value in the $\mathrm{L}^{*} \mathrm{a}^{*} \mathrm{~b}^{*}$ color space). We clarified that FMI began to increase several days before changes in chromaticity. Moreover, after the tomatoes had come to maturity, FMI changed as well as the $\mathrm{a}^{*} / \mathrm{b}^{*}$ value. Experimental results on kiwi fruits 'Hayward' revealed that the FMI changes differed greatly depending on the ripening temperature, and there were good linear correlations between FMI and fruit firmness (during the immature to edible phase) as well as between FMI and sugar/acid ratio (during the immature to fully-ripened phase). These results demonstrate that FMI is applicable to evaluate the maturity of tomatoes and the quality of kiwi fruits. It is thought that this technique can be effectively applied to judge the shipment time and edible period of fruits with constant epicarp color.
\end{abstract}

Keywords: chlorophyll fluorescence, chromaticity, fluorescence maturity index, fruit firmness, sugar acid ratio

2020 年 4 月 23 日受付

2020 年 7 月 9 日受理

*Corresponding author: Ken’ichi Fukuchi (fukuchi@kisarazu.ac.jp)
1. 諸言

近年, 高品質な青果物を求める消費者が多くなり, 収穫か ら流通, 販売に至るまで, その品質を適切に管理することが 求められている ${ }^{1)}$. 特に, クリマクテリック型の果実の場合, 追 
熟により食味評価が大きく変化するため, それらの熟度を精度 よ〈非破壊で評価する手法の確立と装置の開発が課題となつ ている ${ }^{2)}$.すでに, 果実の力学特性や光学特性を利用した非 破壞評価装置が開発され実用化されているが, 大型かつ高 価格なものが多い ${ }^{2)}$. また, 対象となる果実も装置ごとに限定 されることから, 沉用性の高い評価手法と小型で操作が簡便 な装置の開発が望まれる.

我々は, 植物葉のクロロフィル蛍光スペクトルを測定し, 波 長 $685 \mathrm{~nm}$ 付近のピーク（F685）および $740 \mathrm{~nm}$ 付近のピー ク（F740）の強度比 F685/F740 とクロロフィル濃度 $C$ との 関係を調べた結果, $C$ が増加すると F685 がクロロフイル aに 強く再吸収されるために, F685/F740 が減少することを明ら かにした ${ }^{3)}$.ところで, 果実に含まれるクロロフイルは, 成熟に 伴い分解されて減少することが知られている ${ }^{4)}$. 従って, 果実 内部より放出される蛍光スペクトルを測定した場合, 成熟に伴 い, F685 はF740に対して相対的に強く観察されるようにな り, 一定条件のもとでは, ランベルト・ベール則に従い, 果実 内の $C$ と F685/F740 の対数との間に比例関係が成り立つと 予想できる. 以上のことから, 我々は $\log (\mathrm{F} 685 / \mathrm{F} 740)$ を蛍 光計測に基づく果実の熟度指標（FMI: fluorescence maturity index）として利用できるのではないかと考えた. 物 体内部から放出される蛍光スペクトルの計測は, 物体表面に おける光の反射, 吸収, 散乱等の影響を受けにくいため, そ れらの影響を複雑に受ける分光反射スペクトルおよび分光透 過スペクトルの計測 ${ }^{5)}$ と比較すると容易であり, 大きさおよび 凹凸や柔毛の有無等の表面状態が, 種類あるいは個体間で 異なる様々な果実の評価に適していると考えられる. また, 励 起光源として高強度の単色コヒーレント光が得られるレーザを 使用すれば, 広範にわたる非接触計測や時間・空間分解計 測への応用も可能となる ${ }^{6)}$.

これまでに, 採取後のトマト (Solanum lycopersicum L.) を用いた測定を行い, 目視による果皮の着色が観察される前 に蛍光スペクトルに変化が現れ, 成熟に伴い FMI が増加す ることを確認している7 ${ }^{7}$ ，そこで本研究では，まず，大玉卜マト の主要品種の1つである‘ホームモモ夕ロウ’供試して, FMI と果皮色度 (L*a*b*表色系) の関係を調查L, FMI を指標とした熟度評価の可能性抢よび有用性について検討 を行った. 次に, 新たにキウイフルーツ (Actinidia deliciosa) を用いた実験を行った. キウイフルーツは貯蔵性に優れ, ビ夕 ミン C, カロテノイド, 食物瀻維等の機能性成分を豊富に含み 人気の高い果実の一つである ${ }^{8)}$. 一方で, 追熟を誘発させる ために収穫後にエチレン処理を施す必要があり, 収穫時期, 貯蔵条件等に追熟速度が左右されることが知られている 9-11). その上, トマトとは異なり, 追熟に伴う外観上の変化がな いため ${ }^{12}$, 消費者が食感, 甘味, 酸っぱさ等, 自分好みの食
ベ頃を判断するのが難しいという課題がある. そこで, キウイ フルーツの主要品種の 1 つである‘ヘイワードを供試して, 異 なる温度で追熟した際の FMI 変化を調査するとともに, 熟度 の異なる試料を用いて, FMI と果実硬度（以下, 硬度とい う）および味覚のパラメータとなる糖酸比 ${ }^{13)}$ の関係を調査 し, FMI を指標とした品質評価が可能であるか検討を行った。

\section{2. 材料および方法}

\section{1 蛍光スペクトルの測定方法}

FMI を求める基となる蛍光スペクトルの測定装置概要を Fig. 1 に示す. $100 \mathrm{~W}$ のキセハンランプ光源（LAX-103, 朝 日分光製) の放射光を, 可視光照射用のミラーモジュール (MM-VIS, 朝日分光製) と半值幅 $11 \mathrm{~nm}$, 中心波長 620 $\mathrm{nm}$ のバンドパスフィルター（MX0620, 朝日分光製）を用い て単色化した後, 合成石英製の光ファイバー $(\phi 5 \times 1000 \mathrm{~L}$, 朝日分光製）とロッドレンズ（RLQL80-1, 朝日分光製）を通 して集光し, 波長 $620 \mathrm{~nm}$, 強度 $100 \mathrm{~W} \mathrm{~m}{ }^{-2}$ の励起光を, 果 頂部を上に向けた試料の表面赤道付近に垂直照射した. 励 起波長については, 前報 ${ }^{7}$ の結果を踏まえ, リコペン等のカロ テノイドによる吸収が少ない波長を選択した. 試料内部より放 出された蛍光を, 試料表面に設置した光フアイバー（蛍光検 出部) よりマルチチャンネル分光器 (PMA-50, 浜松ホトニク ス製）に導き, 入射スリッ幅 $100 \mu \mathrm{m}$, 露光時間 $400 \mathrm{~ms}$ の 条件においてスペクル計測を行った. 尚, 本装置の詳細な 仕様については, 別報 ${ }^{14,15)}$ に記載されているため省略する.

Fig. 1 の左下に示すように, 励起光の照射点を $\mathrm{E}$, 蛍光検

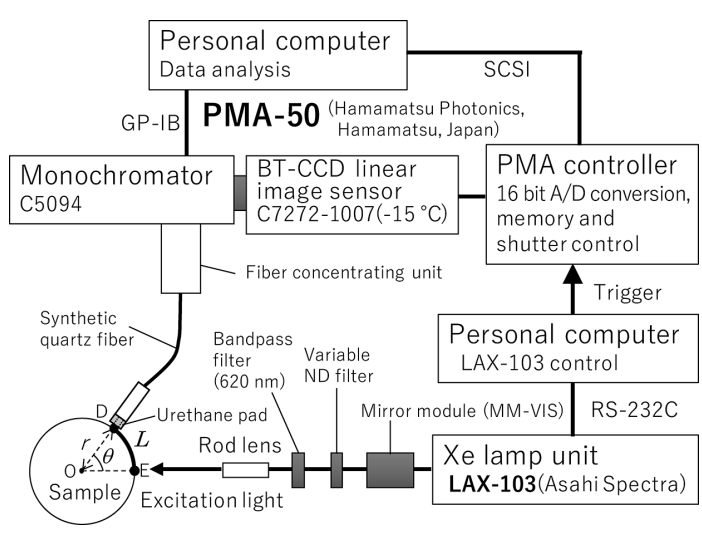

Fig. 1 Block diagram of the device used for fluorescence spectra measurement. The value of $r$ was $30 \mathrm{~mm}, \theta$ was 45 degrees and $L$ was about $24 \mathrm{~mm}$. The intensity of excitation light $(620 \mathrm{~nm})$ on a sample surface was $100 \mathrm{~W} \mathrm{~m}^{-2}$. 
出部を $\mathrm{D}$, 励起光の入射軸と蛍光検出軸の交点を $\mathrm{O}$ とお き, $\mathrm{OE}=\mathrm{OD}=r$ とする. 供試したトマトの平均半径が約 31 $\mathrm{mm}$, キウイフルーツの平均半径が約 $25 \mathrm{~mm}$ であったことか ら, 一連の測定において, $r$ を $30 \mathrm{~mm}$ に固定した. 試料表面 上の弧 $\mathrm{DE}$ の長さを $L$ とする, 同一試料であっても $L$ が異 なれば, 試料中のクロロフイルによる F685 の再吸収の割合が 異なるため, FMI に影響する. $L$ が小さいと, クロロフィル濃 度の変化量に対して F685 の変化量は小さくなり, 指標として の感度が低下する. 逆に $L$ が大きくなると, 蛍光検出部付近 の蛍光強度が小さくなり測定精度が低下する. 前報 ${ }^{7)}$ におい て, トマトの FMI 変化を感度, 精度ともによく観察できたの は, $L$ が $25 〜 35 \mathrm{~mm}$ の範囲であった. 本実験では, $r$ を固 定したので, $L$ は OEと OD のなす角 $\theta$ で決まる. キウイフル 一ツの場合, 予備実験において $\theta$ が $45^{\circ}$ の時に良好な結果 が得られたことから（デー夕は示さず）, $\theta$ を $45^{\circ}, L$ を約 24 $\mathrm{mm}$ に固定し, トマトおよびキウイフルーツともに同じ条件で測 定を行った. 尚, 両果実とも, 蛍光スペクトル測定前の暗順応 は実施しなかった.

\section{2 トマトを用いた実 験}

\subsection{1 試料}

‘ホームモモタロウ’ (タキイ種苗) の断根接木苗を, 約 40 $\mathrm{L}$ の培養土（花と野菜の土 $\mathrm{W}$ 効果, 応用自然科学製) を 入れたプランターに定植し, 千葉県木更津市内において日当 たり良好の場所で栽培した（2019 年 4 月〜 7 月). 開花約 50 日後, 目視により果頂部で緑がわずかに淡く白つぽくなった 時点で緑熟と判断 ${ }^{16)}$ して採取し, 赤道付近の長径が 65 $\mathrm{mm}$, 短径が $60 \mathrm{~mm}$, 質量 $110 \mathrm{~g}$ 程度の果実 13 個を選ん で, 測定用の試料とした.

\subsection{2 蛍光スペクトルおよび果皮色度の測定}

試料採取後, $25^{\circ} \mathrm{C}$ に制御した人工気象室内（日中 12 時 間は約 $100 \mu \mathrm{mol} \mathrm{m}^{-2} \mathrm{~s}^{-1}$ の白色光照射) で, 約 17 日間追 熟し, 1 日ごとに蛍光スペクトルと果皮色度を測定した. 蛍光 スペクトルの測定方法は 2.1 で述べた通りである. 果皮色度 は色度計（TES-135A, TES 製）を用い, 2 視野において CIE L*a*b* 表色系 ${ }^{17)}$ の $a *$ 值, b* 值を測定した. 尚, 蛍光 スペクトルは試料赤道上 2 点について, 果皮色度は 2 点の 中間点を含めて計 3 点について測定を行い, それぞれ平均 して試料の代表值とした. 以後, 同一試料で複数点の測定を 行った場合, すべてそれらを平均して代表值を求めることとす る.

\section{3 キウイフルーツを用いた実験}

\subsection{1 試料}

2018 年 11 月上旬に千葉県松戸市内の果樹園にて, 質量
が $100 \mathrm{~g}$ 程度である中玉の‘ヘイワードをを採取した（樹齢, 開花日は不明). 直ちに保冷されたクーラーボックスに入れて 千葉県木更津市内の実験室に運び, 果実表面に傷および色 ムラがあるものを除外し, 計 35 個の果実を実験に供試した. 試料は各実験操作に応じて A 群 (5 個, $106.29 \mathrm{~g} \sim 108.79$ $\mathrm{g}$ ), B 群 (5 個, $105.83 \mathrm{~g} \sim 112.16 \mathrm{~g}$ ), C 群 (3 個, $104.64 \mathrm{~g} \sim 112.55 \mathrm{~g})$ および D 群 (22 個, $77.21 \mathrm{~g}$ 〜 $96.81 \mathrm{~g})$ の 4 つの群に分類し, エチレン吸着剂（TM-1, オ ルデイ製）とともに $3{ }^{\circ} \mathrm{C}$ と設定したクールインキュベータに入 れ, 貯蔵した.

\subsection{2 蛍光スペクトルの測定}

採取 4 日後に, 貯蔵していたキウイフルーツのうち, A 群 (5 個), B 群（5 個）および C 群（3 個）をクールインキュ ベータより取り出し, 各試料（計 13 個）の赤道上 2 点につ いて, まず, 初日の蛍光スペクトル計測を行った. その後, A 群は, そのまま $3{ }^{\circ} \mathrm{Cに}$ 設定したクールインキュベータに戻して 貯蔵した. B 群と C 群は, エチレン処理を施した後, B 群は $17.5{ }^{\circ} \mathrm{C}, \mathrm{C}$ 群は $25^{\circ} \mathrm{C}$ 設定したインキュベー夕内で追熟を行 つた. 各群の全試料について, 2 日ごとにインキュベータより取 り出し, 初日と同様に蛍光スペクトル測定を行った. 尚, 試料 の乾燥を防ぐため, 蛍光スペクトル測定時以外は, 約 $2 \mathrm{~mm}$ の小穴を 10 個程度開けたポリエチレン袋に入れて保管した.

\subsection{3 エチレン処理}

試料とゼオライトエチレン約 $1.7 \mathrm{~g}$ を含む果実追熟剂（熟 れごろ, 日本園芸農業協同組合連合会製）とをポリエチレン 袋 $(280 \mathrm{~mm} \times 200 \mathrm{~mm}$, 厚さ $0.04 \mathrm{~mm})$ に入れて密封し, 48 時間のエチレン処理を行った. エチレン処理中の温度は, そ

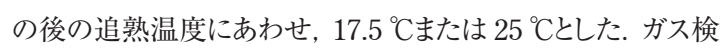
知管 (No. 172, ガステック製) で測定したポリエチレン袋内 のエチレン濃度は, 処理開始より 1 時間後および 24 時間後 は $1600 \mathrm{ppm}, 48$ 時間後は $500 \mathrm{ppm}$ であった. 尚, 温度以 外の条件をそろえるため, 各エチレン処理の際, 1 枚のポリエ チレン袋に入れる試料の数は 5 個とした.

\subsection{4 硬度および糖酸度の測定}

採取約 6 週間後に, $3{ }^{\circ} \mathrm{C} て ゙$ 貯蔵していた D 群 (22 個)を クールインキュベータより取り出し, 追熟しながら FMI と硬度お よび糖酸度との関係を調べた。

まず, クールインキュベータより取り出した直後の D 群 22 個 の中から任意に 2 個を選び, 赤道付近 4 点の蛍光スペクトル 計測を行い, FMI を求めた. その後, 同 4 点の硬度を次の 方法で測定した. Fig. 2 に示したように, 最大荷重が $5 \mathrm{~kg}$ あ るいは $1 \mathrm{~kg}$ である果実硬度計（KM-5 あるいは KM-1, 藤 原製作所製）の本体部分を $\mathrm{X}$ 軸ステージに固定した. マイク ロメータを回転させ, 直径 $5.0 \mathrm{~mm}$ (断面積約 $0.20 \mathrm{~cm}^{2}$ ）の 円筒型プランジャーを約 $5 \mathrm{~mm} \mathrm{~min}^{-1}$ の一定速度で表皮を薄 


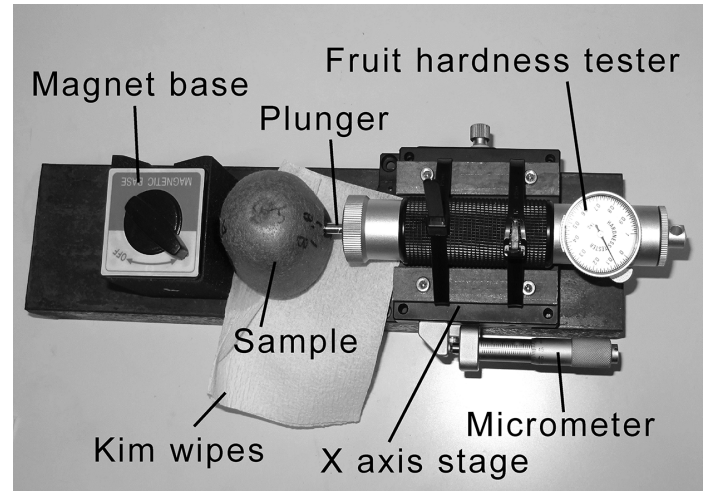

Fig. 2 Image of the fruit firmness measurement device. The micrometer was rotated, and the tester (KM-5 or KM-12, Fujiwara Scientific Company, Tokyo, Japan) was moved at a constant rate (about $5 \mathrm{~mm} \mathrm{~min}^{-1}$ ). The maximum load value when the cylindrical plunger $\left(5.0 \mathrm{~mm}\right.$ in diameter, $0.20 \mathrm{~cm}^{2}$ in cross-sectional area) had penetrated $5.0 \mathrm{~mm}$ was measured.

く削いだ試料表面に挿入していき，果実表面より $5.0 \mathrm{~mm}$ 貫 通した際の最大荷重值を読み取り, プランジャーの断面積で 除した值を $\mathrm{kg} \mathrm{cm}^{-2}$ で表し, その点における硬度とした. 尚, $1.0 \mathrm{~kg} \mathrm{~cm}^{-2}(9.8 \times 10 \mathrm{kPa})$ のように圧力換算值も併記する. 硬度測定後, 試料の赤道部分約 $40 \mathrm{~g}$ を切りだし, ミキサーで 粉砕した後にろ過して得られた果汁について, キウイ専用の ポケット糖酸度計（PAL-BX|ACID8, アタゴ製）を用いて糖 酸度を測定した。

次に, 残りの D 群 20 個について, 5 個ごとにポリエチレン 袋に入れて 2.3 .3 で記述した方法で温度 $17.5{ }^{\circ} \mathrm{Cにおいてエ}$ チレン処理を施した後, $17.5{ }^{\circ} \mathrm{C}$ 設定したインキュベータ内で 追熟を行いながら, 適宜, 蛍光スペクトル, 硬度および糖酸 度の測定を行った.

\section{3. 結果と考察}

3.1 トマトおよびキウイフルーツの蛍光スペクト ル変化

Fig. 3 に緑熟で採取したトマト‘ホームモモ夕ロウ’およびエ

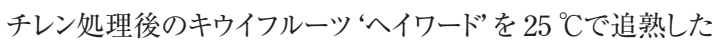
際の蛍光スペクトル変化の典型例を示す.

まず, トマトの蛍光スペクトル変化を見ると, 採取直後（追 熟 0 日目）の状態では, F740が大きく観察されたが, F685 は非常に小さくなっている. 前報 ${ }^{7)}$ において, 緑熟のトマト果 実断面における蛍光分布を測定した結果, 果実の内部にお

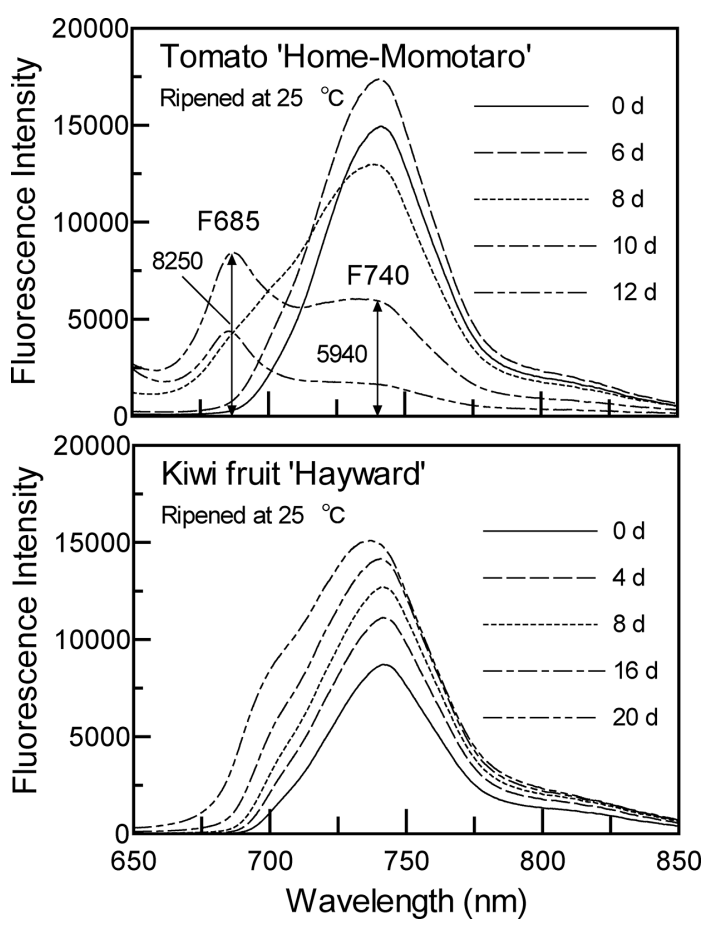

Fig. 3 Typical fluorescence spectra variations during ripening. The upper graph shows the results for tomato 'Home-Momotaro' and the lower graph shows those for kiwi fruit 'Hayward'. The ripening period is given in the legend of each graph. FMI was defined as the logarithm of F685/F740.

いては F685も強く観察されたことから, 短波長側の F685 は, 果実中のクロロフィルに強く再吸収されてしまい, 果皮表 面の蛍光検出部まで到達できなかったと考えられる. 追熟 6 日目では, F685 と F740 ともに僅かな増加がみられた. このこ とは, 果実内部に含まれるクロロフイルの分解が始まり ${ }^{18)}$, 励 起光がより果実内部まで進入できるようになった結果, 蛍光検 出部付近の蛍光強度が増加したと考えれば説明できる. 追 熟 8 日目以降は, さらに果実内部のクロロフィル濃度が減少し たためにクロロフィル蛍光自身が弱くなり F740 は減少に転じ, 一方で, クロロフイルによる再吸収効果が小さくなったため, F685 は相対的に強く観察されるようになったと考えられる. 追 熟 10 日目になると, F685 は F740 より大きくなり, 明確なピーク として観察されるようになった. 10 日目の蛍光スペクトルを基に FMI を計算すると,

$$
\mathrm{FMI}=\log (\mathrm{F} 685 / \mathrm{F} 740)=\log (8250 / 5940) \doteqdot 0.14
$$

となる.

次に, キウイフルーツの蛍光スペクトル変化を見ると, 追熟前 
（0日）の F740 は，追熟前のトマトと比較すると，三分の二以 下であり, 追熟日数が増すとともに徐々に増加した. 果実内部 のクロロフィル濃度は, キウイフルーツの方がトマトより高いた め, 追熟前は励起光が試料内部まで進入できずに蛍光検出 部付近の蛍光強度は小さく, 追熟によるクロロフィルの減少に 伴い, 徐々に蛍光強度が増加したものと考元らる. 一方, F685に関しては，追熟前にはほとんど観察されず，追熟に伴 い徐々に増加するものの, 追熟 20 日目に果実からアルコール 臭がするようになっても, トマトと異なり明確なピークとして観察 されることはなかった，追熟に伴って果実内部も赤変するトマ卜 とは異なり, キウイフルーツの果実内部は追熟後も濃緑色を示 しており, 相当量のクロロフィルが存在していると考えられる. これらの違いが, トマトとキウイフルーツの蛍光スペクトル変化 の違いとなって観察されたものと考えられる.

尚, Fig. 3 に示した蛍光スペクトルより (1) 式同様に FMI を計算すると, トマトについては, 追熟前が約 -1.8 , 追熟 12 日目が約 0.4 , キウイフルーツについては追熟前が約 -2.5 , 追 熟 20 日目が約 -0.7 であった. F685 が明確なピークとして観 察されないキウイフルーツに挍いても, 追熟により FMI が増加 することが確認できた。

\section{2 トマトのF M I と果皮色度の関係}

一般にトマ卜果実の熟度は, 果皮色度 ( $\mathrm{L}^{*} \mathrm{a} * \mathrm{~b}$ *表色系) の $\mathrm{a} *$ 值あるいは $\mathrm{a} * / \mathrm{b} *$ 值を用いて評価される場合が多 $w^{19}$. 特に, $\mathrm{a}^{*} / \mathrm{b}^{*}$ 值は, 追熟初期（催色期〜半熟期）に おいて, 果実の頂部, 腹部, 底部でほぼ同様の值を示し, 目 視による果実の着色程度との間に比例関係があることが報告 されている ${ }^{20)}$. そこで, 追熟日数に対する FMI, a*值および a*/b*值の変化を比較することにした. ところで, 2.2 .1 で述 べた通り, 緑熟の判断は目視で行ったため, 採取日から着色 開始日までの日数は, 試料ごとに様々であった.つまり, 採取 時点での各試料の熟度は異なっていたと考えられ, 採取日を 基準として日ごとの変化を比較することは適切でない. そこ で, 各試料の $\mathrm{a}^{*}$ 值が負（緑色方向）から正（赤色方向） に転じた日を基準とし, 基準日（0日）の前後 8 日間（-8日 〜 +8 日) の值を比較することとした. 供試した試料 13 個の 中から, 全期間 $(-8$ 日〜 +8 日) でデータが得られた 10 個 の試料について, 日ごとに各指標（FMI, a*值, $a * / b *$ 值) の平均值を求めた. 結果を Fig. 4 に示す.

初日（-8日）と最終日（+8日）での各指標の值拈よびそ の変化量は, a*值が約 -12 から約 35 まで約 47 の増加, $\mathrm{a}^{*} / \mathrm{b} *$ 值が約 -0.5 から約 2.2 まで約 2.7 の増加, FMI が約 -1.8 から約 0.5 まで約 2.3 の増加であった. 目視観察の結果 も踏まえ, 変化の様子をグラフ上で比較する. a* 值および a*/b*值については, -8 日から -3 日まで大きな変化はなくほ
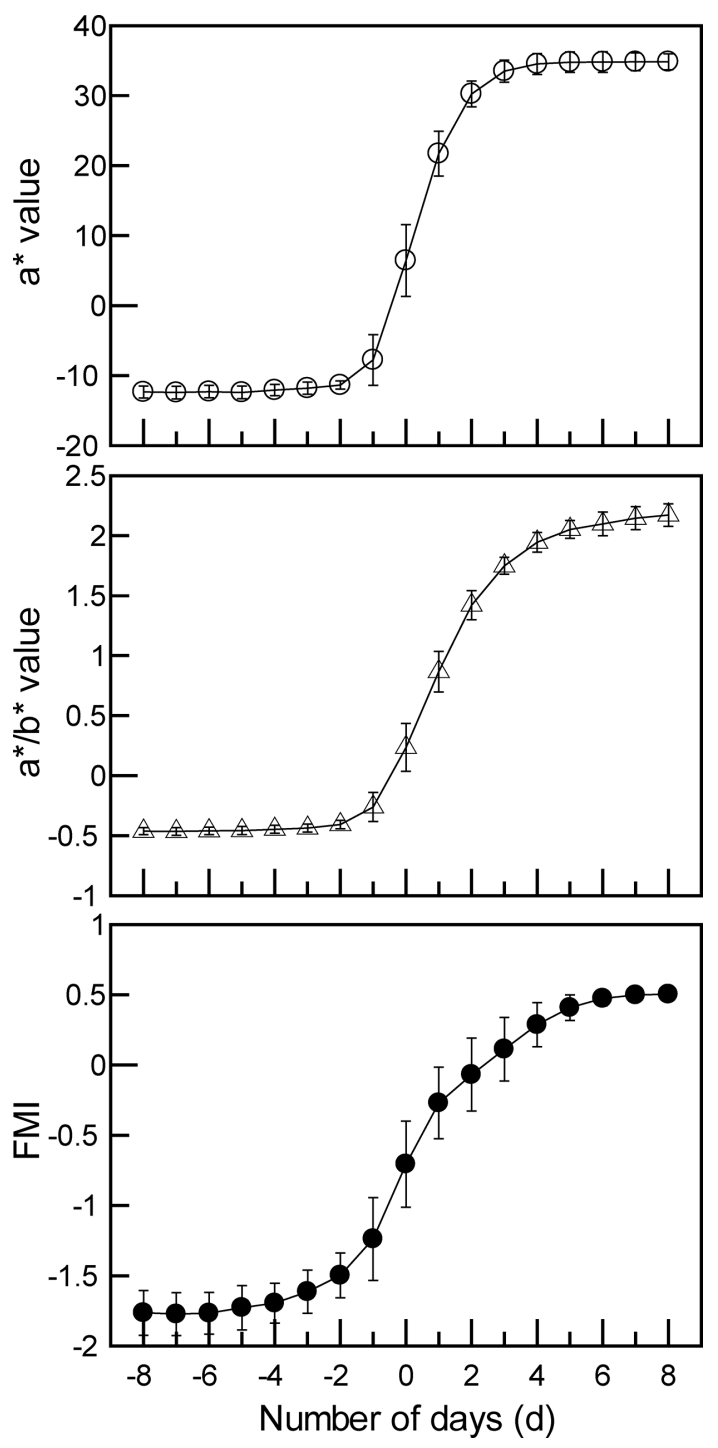

Fig. 4 Changes of FMI, $\mathrm{a}^{*}$ value and $\mathrm{a}^{*} / \mathrm{b}$ * value in tomato 'Home-Momotaro' during ripening. "0" of the horizontal axis indicates the day when the $\mathrm{a}^{*}$ value changed to positive (plus) from negative (minus). Each plot was a mean value of 10 samples, and the error bars show standard deviations $( \pm \sigma, \mathrm{n}=10)$.

ぼ一定であり, 果皮色も緑色のままであった. -2 日に $\mathrm{a}$ *值は 約 $-11, \mathrm{a}^{*} / \mathrm{b}$ *值は約 -0.4 とわずかに増加したが, ほとんど の試料で果皮色の変化は観察されなかった. -1 日になると a* 值は約 $-8, a * / b *$ 值は約 -0.3 まで増加し, 目視でも果実 の一部がわずかに着色したことが確認できた. a*值および $\mathrm{a}$ */b*值がプラスに転じた基準日（0日）には, 果実全体に 橙赤色が広がったことが確認できた. +1 日以降, 両值ともに 


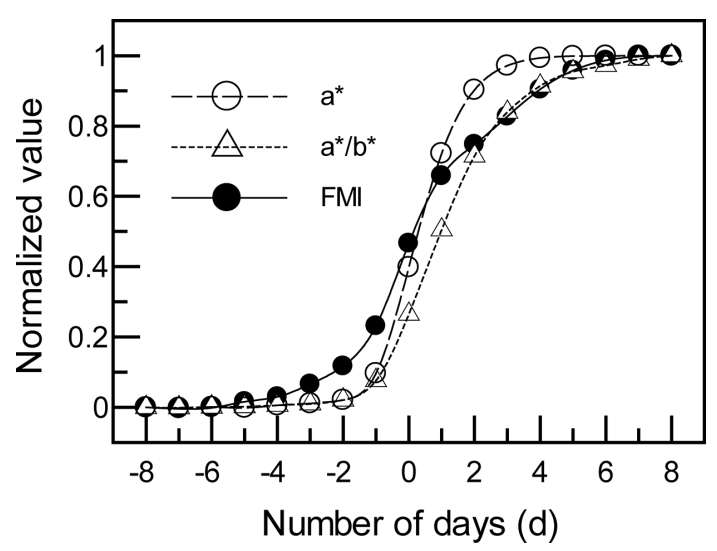

Fig. 5 Comparison of FMI, a* value and $\mathrm{a}^{*} / \mathrm{b}^{*}$ value after normalization. The data in Fig. 5 is a normalized representation of the data in Fig. 4 as follows: each index value before ripening (value of $-8 \mathrm{~d}$ ) was assumed to be 0 and that after ripening (value of $+8 \mathrm{~d}$ ) was assumed to be 1.

急増したが, $a^{*}$ 值は +4 日に +35 となり増加が止まり, それ以 降は一定值を保った. 一方, $\mathrm{a}^{*} / \mathrm{b} *$ 值については, +4 日に約 1.9 になった後, +8 日に約 2.2 となるまで増加を続けた. 目視 では, +2 日に完全に着色して完熟した後, 少しずつ赤味が深 〈なり, +8 日には, 赤色が黒みをおび, 肉質の軟化も確認でき たことから過熟の状態に達したと考えられる ${ }^{16)}$. FMIについ は, -5 日に約 -1.7 となり, 初期值よりわずかな増加がみられ た. Fig. 4 のエラーバーが示す通り, -5 日付近では, a*值お よび $\mathrm{a} * / \mathrm{b} *$ 值と比べFMIの偏差が大きいことから, Microsoft EXCELのデータ分析ツール（ $\mathrm{t}$ 検定：一対の標 本による平均の検定）を用いて, -8 日と -5 日の值を検証し た結果, 有意差が認められた $(\mathrm{P}<0.05)$. -5 日以降, +8 日ま でFMI は増加を続け, 全体としてはシグモイド曲線に近い変 化となった.

FMI と $\mathrm{a} *$ 值および $\mathrm{a} * / \mathrm{b} *$ 值の変化の割合を比較するた め, 各指標の -8 日の值を $0,+8$ 日の值を 1 として正規化を 行い, Fig. 5 に再プロットした. Fig. 5 より, FMIは-5日から 基準日（0日）までの間, $\mathrm{a}^{*}$ 值および $\mathrm{a}^{*} / \mathrm{b} *$ 值を上回る割合 で増加したことがわかる. また, 完熟したと考えられる +2 日か ら過熟となったと考えられる +8 日までの間, FMI は $\mathrm{a} * / \mathrm{b} *$ 值 とほぼ同じ割合で変化をした. 永田ら ${ }^{18)}$ が抽出法により求め た卜マト果実の各追熟段階における色素含有量を見ると, 緑 熟期から半熟期にかけて, クロロフィルは最大含有量に対し て約 7 割の減少, 同じくリコペンおよび $\beta$ - カロテンはそれぞ れ約 1 割および約 3 割の増加であった. 緑熟期から半熟期 におけるクロロフィル含有量の変化の割合が, リコピンおよび $\beta$-カロテンのそれより大きいため, -5 日から 0 日まで FMI の
変化の割合が $\mathrm{a} *$ 值および $\mathrm{a} * / \mathrm{b} *$ 值の変化の割合を上回っ たと考えられる.

以上のことから, FMI を指標として, 緑熟期から過熟期の すべての段階でトマトの熟度評価を行うことが可能であること がわかった. 特に, 果皮色度に変化があらわれる数日前より FMI の増加が始まることから, 出荷時期の判断を行う上で, 本手法を有効に利用できると考えられる.

\section{3 異なる温度で追熟したキウイフルーツの FMI 変化}

エチレン処理を行わず $3{ }^{\circ} \mathrm{C} て ゙$ 貯蔵した試料 (A 群), エチ レン処理を行い $17.5{ }^{\circ} \mathrm{C} て ゙$ 追熟した試料 (B 群) および $25{ }^{\circ} \mathrm{C}$ で追熟した試料 (C 群) の FMI 変化を Fig. 6 に示す. 追 熟前の FMI は, 全群とも約 -2.5 であった.

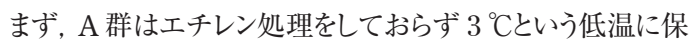
ったにもかかわらず, 10 日目以降に FMI は少しずつ増加しは じめ, 30 日後には約 -2.2 までになった. この状態で貯蔵した 場合でも, 僅かずつクロロフイルが分解されると考えられる.

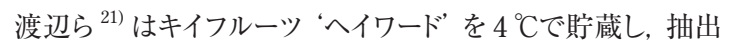
法により総クロロフィル含量を測定した結果, 貯蔵に伴って総 クロロフィル含量が減少することを報告しており, 本測定もこれ に矛盾しない結果となった。

次に, B 群の FMI 変化だが, 4 日目〜 10 日目にかけて約 -1.8 まで急激に増加（初期急増）し, その後, 22 日目にか け約 -1.4 まで緩やかに増加 (中期緩増), 24 日目以降は再 び急増 (後期急増) に転じ, 30 日目に約 -0.8 となった. 追

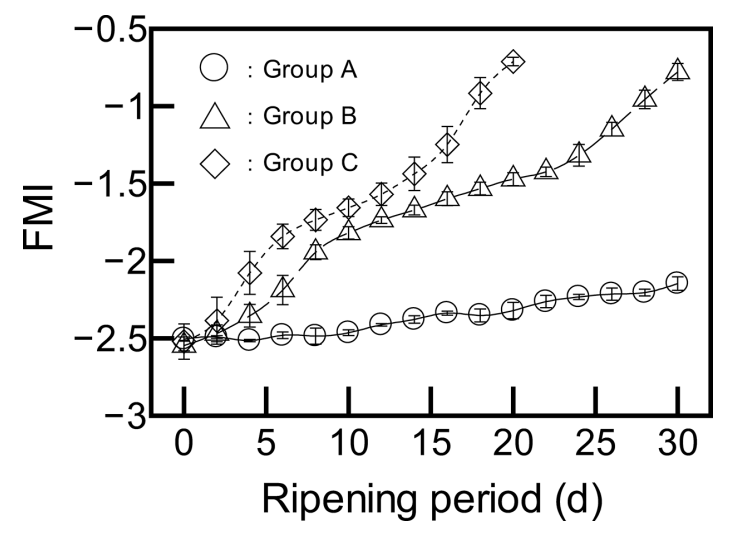

Fig. 6 Changes of FMI in kiwi fruits 'Hayward' under different ripening conditions. Group A: 3 samples stored at $3{ }^{\circ} \mathrm{C}$ without ethylene pretreatment, Group B: 5 samples ripened at $17.5{ }^{\circ} \mathrm{C}$ after ethylene pretreatment $(48 \mathrm{~h}, 500$ to $1600 \mathrm{ppm}, 17.5^{\circ} \mathrm{C}$ ) and Group C: 5 samples ripened at $25{ }^{\circ} \mathrm{C}$ after ethylene pretreatment (48 h, 500 to $1600 \mathrm{ppm}, 25^{\circ} \mathrm{C}$ ). 
熟 30 日目で, 試料よりアルコール臭と果梗部からの果汁漏れ が観察されたため, 過熟と判断し, 測定を終了した. 一方, C 群の場合, 変化の傾向は, B 群と似ているものの, 初期急増 は 2 日目から, 後期急増は 14 日目から始まり, 20 日目には過 熟の状態となる等, B 群の約三分の二の日数で, FMI が同 程度まで増加した. これより, 追熟温度が高い $\mathrm{C}$ 群の方が $\mathrm{B}$ 群より追熟速度が速いと判断できる。

以上のように, 追熟温度の違いによって, FMI の変化の様 子は, 大きく異なることが明らかとなった. このような温度による 追熟速度の違いは, エチレン処理時の温度およびその後の 追熟温度により, キゥイフルーツ自身によるエチレン生成が開 始されるまでの日数に差があるため ${ }^{9)}$ と考えられる.

\section{4 追熟中のキウイフルーツにおける FMI と硬 度および糖酸比との関係}

キウイフルーツ D 群を用いた追熟実験における, FMI 值と 硬度および糖酸比との関係を Fig. 7 に示す.まず, 追熟前の FMI が約 -2.2 の試料に扔ける硬度は, 約 $14 \mathrm{~kg} \mathrm{~cm}^{-2}$ (約 $\left.1.4 \times 10^{3} \mathrm{kPa}\right)$ であった. その後, FMIに比例して硬度は減 少し, FMI が約 - 1.6 のときに硬度は約 $1.2 \mathrm{~kg} \mathrm{~cm}^{-2}$ (約 1.2 $\times 10^{2} \mathrm{kPa}$ ）となった. 一方, FMI が -1.6 以上の領域では硬 度の減少は, 極めて緩やかなものとなり, FMI が -1.0 になる と約 $0.55 \mathrm{~kg} \mathrm{~cm}^{-2}$ (約 $5.4 \times 10 \mathrm{kPa}$ ）となった. ‘ヘイワード果 実の可食硬度についての報告は多くないが, 硬度 $0.6 \sim 1.2$ $\mathrm{kg} \mathrm{cm}^{-2}\left(6 \times 10 \sim 1.2 \times 10^{2} \mathrm{kPa}\right)$ を可食果とする報告 ${ }^{22)}$ や, $1.0 \sim 1.4 \mathrm{~kg} \mathrm{~cm}^{-2}\left(9.8 \times 10 \sim 1.4 \times 10^{2} \mathrm{kPa}\right)$ がとくに旨 いとする報告 ${ }^{23)}$ を参考にすると, 本実験においては, 硬度の 減少が緩やかになり始める FMI 值 -1.6 前後が可食期と考 えられる. 本追熟条件においては, 追熟前 (未熟) から可食 になるまでの段階では, FMI $(\mathrm{X})$ と硬度 $\left(\mathrm{Y}_{\mathrm{f}}\right)$ の間に $\mathrm{Y}_{\mathrm{f}}=-22.1 \mathrm{X}-34.1\left(\mathrm{R}^{2}=0.977, \mathrm{P}<0.001\right)$ のよい直線関係 を見出すことができた. 尚, 採取してから追熟を開始するまで の貯蔵期間が, $\mathrm{D}$ 群と B・C 群では異なるため, 単純には比 較できないが, Fig. 6 において, FMI 值が -1.6 程度となるの は, $\mathrm{B} \cdot \mathrm{C}$ 群ともに, 中期緩増が観察された時期であり, B 群 (追熟温度 $17.5^{\circ} \mathrm{C}$ ) では追熟 14 日目, C 群（追熟温度 25 $\left.{ }^{\circ} \mathrm{C}\right)$ では追熟 10 日目前後と考えられる.

次に, 果実のおいしさを最も直接的に表すパラメータである 糖酸比 ${ }^{13)}\left(\mathrm{Y}_{\mathrm{s}}\right)$ に関しては, 追熟前の約 7 から完熟後の約 18 まで増加し, 未熟から完熟に至るまでの全段階にわたって $\mathrm{FMI}(\mathrm{X})$ との 間 に, $\mathrm{Y}_{\mathrm{s}}=10.2 \mathrm{X}+28.5\left(\mathrm{R}^{2}=0.889, \mathrm{P}<\right.$ 0.001）の直線関係がみられた. ヘイワード可食果の糖度は 約 $13 \%$, 酸含量は約 $1.1 〜 1.2 \%$ とする報告 ${ }^{22)}$ を参考にす ると, 糖酸比で約 $11 〜 12$ となる. これを糖酸比と FMI との 関係式に代入すると FMI は $-1.7 \sim-1.6$ となり, 可食果の

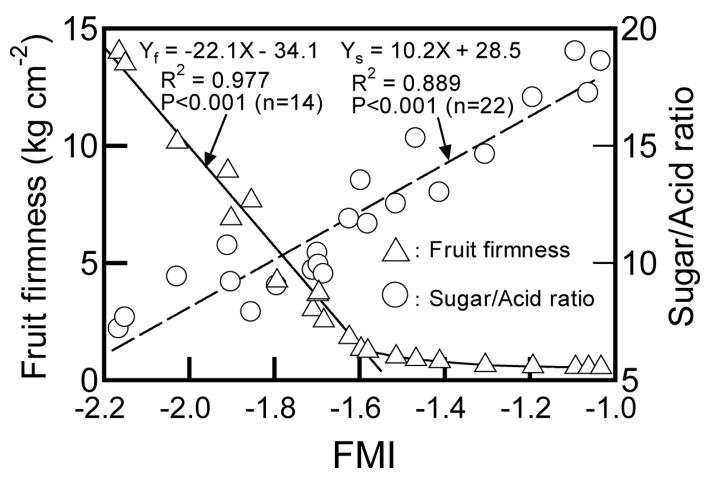

Fig. 7 Relationships between FMI and fruit firmness $(\triangle)$ and FMI and sugar/acid ratio $(O)$ in 'Hayward' kiwis at various stages of maturity. The samples (Group D) had been preserved at $3{ }^{\circ} \mathrm{C}$ for six weeks after harvesting and ripened at $17.5{ }^{\circ} \mathrm{C}$ after ethylene pretreatment $\left(48 \mathrm{~h}, 500\right.$ to $\left.1600 \mathrm{ppm}, 17.5{ }^{\circ} \mathrm{C}\right)$. Fruit firmness $\left(\mathrm{kg} \mathrm{cm}^{-2}\right)$ was calculated by dividing the maximum load value by cross-sectional area $\left(0.20 \mathrm{~cm}^{2}\right)$ of the cylindrical plunger.

硬度に対応した FMI 值 - 1.6 とほぼ一致する. また, それ以 降のさらなる追熟により, 糖酸比が増加するため, 味覚的に は, より甘いと感じるようになると予想される. Fig. 7 のグラフを 参照すれば, FMI の值から硬度と糖酸比の両方を推定する ことが可能となるため, 消費者の好み (硬度, 味覚) にあっ た食べ頃の判断に利用できると考えられる.

キウイフルーツの追熟速度は, 貯蔵条件 (期間, 温度), エチレン処理条件 (濃度, 時間, 温度), その後の追熟温度 で大きく異なり, さらに産地や個体差も大きく影響する ${ }^{9-12)}$. 容 易に FMI が測定できれば, 個体に適した追熟条件の設定や 食べ頃に合わせた出荷が可能となる等, 生産者ニーズに対 応できると考える. また, 緑色のまま完熟するミニトマトの品種と して注目されている‘みどりちゃん’, 西洋ナシの‘ラ・フランス’, 白桃の ‘さくら’といった, 果皮色の変化がほとんど観察されな

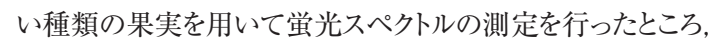
追熟により FMI が増加することが確認できた（デー夕は示さ ず).これらの品種に対しても, 硬度や糖酸比等と FMI との 関連を調査することで, 本手法による熟度評価が可能になる と考える. 一方, 本研究では, 蛍光スペクルルの測定に, 励起 光源としてキセノンランプ, 蛍光検出器としてマルチチャンネル 分光器を使用しており, このままでは汎用性が低い. そこで, 今後, 半導体レーザあるいは高輝度 LED を励起光源とし, 高感度フォトダイオードと狭域バンドパスフィルターを組み合わ せて蛍光検出を行うことで, 安価で携行可能な計測器を開発 することを検討している. 


\section{4. 摘要}

果実内部から放出されるクロロフィル蛍光スペクトルを測定 し, クロロフイル濃度と密接に関連する蛍光強度比 F685/ F740 の対数を指標（FMI）として, 非破壊で果実の熟度お よび品質評価が可能であるか検討を行った.

緑熟のトマト ‘ホームモモ夕ロウ”を追熟し, FMI と果皮色度 (a*值㧍よび $\mathrm{a} * / \mathrm{b} *$ 值) との関係を調べた結果, 果皮色度 に変化があらわれる数日前より FMI の増加が始まり, 完熟後 は $\mathrm{a}$ */b*值と同様の変化をすることが明らかとなった. キウイ フルーツ・ヘイワードを用いた実験では, 追熟温度により FMI の変化が大きく異なること, 一定条件で追熟を行った場 合, FMI と硬度との間では未熟から可食までの段階におい て, FMI と糖酸比との間では未熟から完熟に至る全段階に おいて，それぞれ直線関倸があることがわかった。

以上のことから, 同一装置による蛍光スペクトル計測に基づ き, FMI を指標としてトマトの熟度評価およびキウイフルーツの 品質評価を行うことが可能であり, 本手法は, 追熟しても果 皮色が変わらない果実の出荷時期や食べころの判定に有用 であると考えられる。

\section{謝辞}

本研究は JSPS 科研費 JP18K05913 の助成を受けた.

\section{引用文献}

1）石川豊. 包装資材の特性に基づいた青果物の輸送並 びに貯蔵中の品質保持に関する研究. 日本食品保蔵科 学会誌. 42: 29-33. 2016.

2) 大森定夫, 平田晃, 鷹尾宏之進, 中元陽一, 藤岡修. 青果物の非破壊品質評価技術に関する開発研究. 農 業機械化研究所研究報告. 40: 1-64. 2011.

3) 高橋邦夫, 峰内 (福地) 健一, 江森康文, 小林智, 石 井弘允. レーザ誘起蛍光法による植物の生育状態のモ

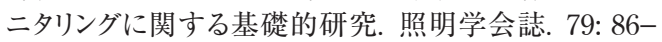
92. 1995.

4）立木美保. エチレンによる果実の成熟・老化制御機構. 果樹研究所研究報告. 6:11-22. 2007.

5）社団法人照明学会編. 光の計測マニュアル. 日本理工 出版会, 東京. 352-369. 1990.

6) 大澤敏彦, 小保方富夫. レーザ計測. 裳華房, 東京. 1-26. 1994.

7）福地健一, 嘉数祐子. クロロフイル蛍光計測による大玉卜
マトの熟度評価. 木更津工業高等専門学校紀要. 52 : 41-48. 2019.

8）西山一朗. キウイフルーツの消化促進効果に関する研究 動向ーアクチニジンの役割-. 栄養学雑誌. 72: 292301. 2014.

9) 矢野昌充. キゥイフルーツの追熟特性の解明ならびに高 品質化に関する研究. 日本食品保蔵科学会誌. 29: 5155. 2003.

10）村上覚, 鈴木麻友, 服部憲明, 佐々木俊之. キウイフル ーツ“レインボーレッドの収穫時期および予冷条件の違 いが 1-MCP の処理効果に及ぼす影響. 園芸学研究. 15: 73-79. 2016.

11）村上覚, 神谷健太, 佐々木俊之. キウイフルーツ`レイン ボーレッドに拈りる弾性指標による熟度の評価. 園芸学 研究. 16: 89-93. 2017.

12）澤田達也, 瀬尾康久, 森嶋博, 芋生憲司, 川越義則. キウイフルーツの貯蔵および追熟に関する研究 (第 1 報). 農業機械学会誌. 54: 61-67. 1992.

13) 伊藤三郎. 果実の機能と科学 (食物と健康の科学シリ ーズ ). 朝倉書店, 東京. 63-67. 2011.

14) 嘉数 (大野) 祐子, 福地健一, 高橋邦夫. 2 種の UV 励起光によるラッカセイ生葉の LIF スペクトル変化および 蛍光葉内分布. 植物環境工学. 22: 100-106. 2010.

15) 福地健一, 嘉数 (大野) 祐子. UV-B 照射がラッカセイ 葉の蛍光スペクトルおよび表皮の分光透過特性に及ぼ す影響. 植物環境工学. 28: 18-28. 2016.

16）農文協編. トマ卜大辞典. 農山漁村文化協会, 東京. 163-180. 2015.

17) 財団法人日本色彩研究所編. 色彩科学入門. 日本色研 事業株式会社, 東京. 49-63. 2000.

18）永田雅靖, 山下市二. トマト果実に含まれるクロロフィル およびカロテノイドの同時, 簡便定量法. 日本食品工業 学会誌. 39: 925-928. 1992.

19）菅理哉, 小出章二, 折笠貴寛, 中村宣貴, 椎名武夫. 保蔵温度の異なる緑熟トマトの追熟における果皮色, 積 算エチレン生成量および果実品質の変化. 日本食品保 蔵科学会誌. 40: 279-283. 2014.

20）繆冶棟, 堀部和雄, 加藤元保, 青木勝平, 岩井静子. トマト果実の色と食味の関係. 植物工場学会誌. 12 : 242-247. 2000.

21）渡辺慶一, 高橋文次郎. 緑色系, 黄色系キウイフルーツ 果実の発育および貯蔵中のクロロフィル, カロテノイド色 素. 園芸学会雑誌. 68: 1038-1043. 1999.

22) 小原均, 岡本敏, 岸田佳子, 大川克哉, 松井弘之, 平 田尚美, 高橋英吉. エセフォン処理がキウイフルーツ‘ イワード果実の樹上成熟に及ぼす影響. 園芸学会雑 誌. 66: 273-281. 1997.

23）伊藤三郎, 橋永文男. エチレンによるキウイフルーツの追 熟促進. 鹿兒島大学農学部学術報告. 35: 49-53. 1985. 